\title{
DISCUSSION
}

\section{A PRELIMINARY STUDY ON LEXICAL COHESIVE DEVICES IN READING TEXTS IN THE TEXTBOOK TIẾNG ANH 10 PUBLISHED BY VIETNAM EDUCATION PUBLISHING HOUSE}

\author{
Nguyen Hoang Minh*1, Dong Thi Thuy ${ }^{2}$ \\ 1. University of Huddersfield, Queensgate, Huddersfield, HDI 3DH, United Kingdom \\ 2. Hanoi National University of Education, 136 Xuan Thuy street, Cau Giay district, Hanoi, Vietnam
}

Received 18 July 2020

Revised 16 September 2020; Accepted 24 January 2021

\begin{abstract}
The research examines the lexical cohesive devices in the textbook Tiếng Anh 10 published by Vietnam Education Publishing House. This study employs a documentary method of analysis to answer the research question. In particular, Halliday and Hasan's framework of cohesion in discourse (1976) was adopted to investigate ten reading texts in the reading section. The findings show that in terms of reiteration, repetition is the most frequently used device in all reading texts to make the reading semantically related, while collocation cohesion produces cohesive effects among words and phrases in the same collocational environment. As a result, students will benefit greatly from such lexical cohesion in terms of grasping the meaning of the reading texts, and boosting their reading comprehension and theme-based vocabulary. Hopefully, this article is a preliminary study for further research on applying lexical cohesion in teaching and learning reading comprehension or writing skills.
\end{abstract}

Key words: reading skills, cohesive devices, lexical cohesive devices, discourse analysis, Tiếng Anh 10

\section{Introduction}

In the technology-driven world, students are given great opportunities to access learning tools and authentic materials such as songs, films, news, podcasts, or E-books on the Internet and on a daily basis. However, one of the major and compulsory learning materials for Vietnamese students to acquire language is the textbook. Thanks to the educational reform in 2013, the new series of the textbook for Vietnamese high school students were published by the Vietnam Education Publishing House with Hoang Van Van as the chief editor and until now almost all students over the country have been studying these books. These new textbooks have been nationally acclaimed for their more interesting content with more focus on developing students' English skills. Therefore, how to make the most of the reading texts to improve vocabulary, grammar and writing skills based on some linguistic features,

\footnotetext{
* Corresponding author. Tel.: 44-7593430226

Email: minh10061998@gmail.com
}

especially cohesive devices, seems to be a topic of great concern for both teaching and learning English. In addition, many people have done research on this field; however, they focused on grammatical cohesion (Soraya, 2012), lexical cohesion in reading comprehension (Adel \& Saeide, 2013), and cohesive devices in reading texts in Tiếng Anh 12 (Bui, 2011). To the best of the researchers' knowledge, no studies have analyzed cohesive devices in reading texts in the textbook Tiếng Anh 10, hence this article was conducted to address this gap.

\section{Literature review}

\subsection{Reading}

There are a number of different definitions of reading. Among them, Koda (2005, p. 4) views that reading is the procedure of extracting and connecting countless information from the reading text and prior knowledge while Smith (2004, p. 27) states that reading is a special thinking process in which thought is prompted 
by a written text, which includes literal, evaluative and inferential comprehension.

With regard to reading skills, Clark and Rumbold (2006) notes that they refer to the ability to comprehend a written text. When students are able to understand a piece of written text and combine their understanding with prior knowledge, they are able to perform the following reading comprehension skills, namely literal comprehension, evaluative comprehension and inferential comprehension. To master these skills, knowing strategies is of great importance. Duffy (2009) identifies strategy as a plan to follow and adjust if necessary. In the context of reading, there are plenty of strategies leading to successful reading. Some are predicting, inferring, summarizing, scanning and skimming.

\subsection{Discourse and cohesion in discourse}

Discourse has been increasingly common in the academic and non-academic fields. The term "discourse", far and wide, has been defined in various ways. Crystal (1992, p. 25) claims that discourse is "a continuous stretch of language larger than a sentence, often constituting a coherent unit". According to Halliday and Hasan (1989, p. 38), discourse is simply defined as "language that is functional". From the aforementioned extracts, discourse tends to be defined in terms of meaning, and coherence is considered an irreplaceable element to form meaning as a whole. What is more, discourse is often described as "language-inuse", thus referring to the interpretation of the communicative event in context.

From these definitions of discourse, it is understandable that discourse analysis is defined as "the study of the relationship between language and the contexts in which it is used" (McCarthy, 1991).

According to Halliday and Hasan (1976, p. 4), the concept of cohesion is a semantic one that points out the relations of meaning existing within a text. Cohesion, along with coherence, plays an integral role in defining a text. In the discourse, if the interpretation of certain elements depends on that of others, cohesion occurs, then the relation of cohesion is established. In other words, one item presupposes the other. Take the following text as a telling example:
"Sam didn't come to the party. He came back home to visit her grandmother".

The interpretation of the item "He" completely depends on the lexical item "Sam". Therefore, the text is considered cohesive as readers cannot understand who is "he" if "Sam" does not exist in the text.

According to Halliday and Hasan (1976, p. 13), cohesive devices are elements that have the "property of signaling that the interpretation of the passage in question depends on something else". In much other research, the term can be attributed to other names such as "cohesive ties", "cohesive connectors", "cohesive markers"; however, the function and meaning remain the same.

Halliday and Hasan (1976, p. 6) state that cohesion is expressed partly through grammar and partly through vocabulary. Hence, it is divided into grammatical cohesion and lexical cohesion.

Lexical cohesion is one of the main types of cohesion dealt with in Hasan and Halliday (1976). Unlike the sub-types of grammatical cohesion, namely reference, ellipsis, substitution, and conjunctive cohesion, lexical cohesion is not associated with any syntactic classes of elements. Lexical cohesion occurs when words in discourse are semantically related in some way. Lexical cohesion is divided into two main types: reiteration and collocation.

According to Halliday and Hasan (1976), reiteration is "the repetition of a lexical item, or the occurrence of a synonym of some kind, in the context of reference; that is, where the two occurrences have the same referent". Reiteration consists of repetition, synonyms or near synonyms, super-ordinate and general words.

\section{Reiteration}

Repetition is the restatement of the same lexical item. This is demonstrated by the following example.

As a result of this process, radiant energy from the sun is stored as chemical energy. In turn, the chemical energy is used to decompose carbon dioxide and water. (Pamela, 2004, p. 273)

"Chemical energy" is entirely repeated in this example. However, it is claimed that 
reiterated items need not to be in the exactly same morphological shape to be recognized as repeated. Take the following as an example.

In turn, the chemical energy is used to decompose carbon dioxide and water. The products of their decomposition are recombined into a new compound, which successively builds up into the more and more complex substances that comprise the plant. (Pamela, 2004, p. 273)

"Decompose" and "decomposition" are all the same item, and occurrence of any one constitutes a repetition of any of the others. Inflectional and derivational variants are also considered repeated.

Synonym is used to refer to items of similar meaning. This is created by the selection of a lexical item which is in some way synonymous with the proceeding one. Synonymous items can be total or partial. This is illustrated in the sentences below.

A jazz band commonly includes four to twelve musicians with a relatively large proportion of the group in the rhythm section. Customarily, there are a drummer, a bass player, and a pianist. (Pamela, 2004, p. 232)

The shade of meaning of the two items "commonly" and "customarily" is relatively similar, which can be considered partial synonym.

Superordinate refers to any item whose meaning includes that of the earlier one (Halliday \& Hasan, 1976, p. 280). There is a close tie between superordinate and so-called hyponym which refers to items of generalspecific or an example of relationship (Paltridge, 2012, p. 119). As it can be seen in the following sentences.

In May 1966, the World Health Organization (WHO), an agency of the United Nations, was authorized to initiate a global campaign to eradicate smallpox. The goal was to eliminate the disease in one decade. (Pamela, 2004, p. 414)

In the extracted sentence above, "disease", which is a more general term, is a superordinate of "smallpox".

General words, which correspond to the major classes of lexical items, are commonly used with cohesive force. They possibly belong to lexical items and substitutes. According to
Halliday and Hasan (1976, p. 280), there are some common general words such as thing, person, make, do, stuff, ideas and so forth. David (1993, p. 29) gave an example to clarify this point.

A: Did you try the steamed buns?

$B$ : Yes, I didn't like the things much.

The general word "things" is used to refer to the presupposed item itself "steamed buns".

\section{Collocation}

Halliday and Hasan (1976, p. 284) define collocation in its most elemental form as "lexical items that regularly co-occur". As it can be seen in lexical reiteration, the occurrence of different lexical items systematically stands in some kind of semantic relation to one another, yet according to Halliday and Hasan, for textual purposes, such relations do not matter much. There is always possibility of cohesion between any lexical items which are related to others in some way, for example "laugh... joke, blade... sharp, garden... dig, ill... doctor, try... succeed..." (Halliday \& Hasan, 1976, p. 285). The cohesive effect of these pairs does not depend much on meaning relations, but on their sharing the same lexical environment. Hence, collocation in discourse is not "the combination of words formed when two or more words are often used together in a way that sounds correct".

Thus, Halliday and Hasan (1976, p. 287) emphasize that collocation or collocational cohesion is "simply a cover term for the cohesion that results from the co-occurrence of lexical items that are in some way or other typically associated with one another, because they tend to occur in similar environment". There is a need to indicate that collocational cohesion is not restrained to pairs of words nor dependent on grammatical structures. Collocation patterns in terms of discourse can occur freely within sentences or across the whole text. As such, its exact function has always remained problematic (Halliday \& Hasan, 1976, p. 284), Sharing the same viewpoint, David Nunan (1993, p. 30) explains this is due to "collocation is expressed through open rather than closed class items".

\subsection{Previous studies}

There is a plethora of research regarding the analysis of cohesion in reading in different languages and different genres as well. In this 
piece of analysis, it is suggested to review two pieces of research from foreign researchers and one document analysis of a Vietnamese researcher.

Adel and Saeide (2013) conducted a study with the aim of determining if making students aware of lexical cohesion devices in a text can better their reading ability. In this study, 30 male EFL learners aged between 17 and 30 were chosen out of 180 intermediate students at Iran Language Institute. The selection was carried out on the basis of their final scores on the reading section of Intermediate 2 and all of them were Intermediate 3 students at the time of this study performed. The researchers randomly assigned them to two control and experimental groups with 15 students in each group. 10 passages were taught during the term to both groups with the same method predetermined at the Institute. Nevertheless, in the experimental group, they were also given various examples for lexical devices and were asked to identify them in the texts via oral questions and group work. At the end of the term, a T-test was taken to compare the mean scores of subjects in both groups. The results showed a significant improvement in the reading scores in the experimental group. The study mainly focuses on the positive effects of the instructions on lexical cohesive devices in reading comprehension.

Another research focusing on another type of cohesion which is grammatical cohesion was conducted by Soraya in 2012. The research aims at investigating the importance of teaching grammatical cohesive devices to foreign language university learners. The assessment was determined by a two-part test taken by first-year university groups. They were assigned to an experimental group and a control one. The students in the experimental group were taught the major connective ties whereas the control group ones were not. At the end of the study period, both two groups underwent the same tests. The results show that the experimental group could perform better when answering the two tests: the cloze procedure and text comprehension test whereas the control group failed.

On the basis of these findings, some suggestions have been given. Explicit teaching of the connective ties may weaken students' apprehension of reading comprehension. Intense practice of the connective ties through cloze procedures, inference and reference questions, multiple-choice questions are highly recommended. In addition to teaching the grammatical cohesive devices, instructors should also draw more attention to other elements to teach such as vocabulary, spelling, and pronunciation, in order to realize an effective comprehension of the reading passages. Therefore, it is advised to be aware of lexical cohesive devices as well.

In the context of Vietnamese research on cohesive devices, a preliminary analysis (Bui, 2011) is reviewed to have a closer look at the topic. The study aims at describing and analyzing the cohesive devices including grammatical and lexical cohesive devices in reading texts in the new English textbook 12. The data is collected then synthesized to lead to the findings and implications. The findings show that in this book of all 6 sub-types of grammatical and lexical cohesion, reference and collocation are the two most frequently used. Therefore, in teaching, it is suggested that teachers should equip students with this piece of knowledge and provide enough practice.

In this article, it was the researchers' intention to investigate lexical cohesive devices in an entirely new document material, which is the textbook Tiếng Anh 10. Hopefully, this study will fill the gap which all aforementioned studies have not addressed yet.

\section{Methodology}

With the aim to analyze cohesive devices in the English textbook for grade 10 students in terms of lexical cohesion without discussing grammatical one, the research question that the study intends to address is: What are the lexical cohesive devices used in the textbook Tiếng Anh 10?

Tiếng Anh 10 is the first of a three-level English language set of textbooks for the Vietnamese upper secondary school. It follows the systematic and theme-based curriculum approved by the Minister of Education and Training on 23rd November 2012. Tiếng Anh 10 includes 10 topic-based units in total, and each comprises 8 sections taught in eight 45 minute sections. They are arranged in order as follows:

1. Getting started

2. Language 
3. Reading

4. Speaking

5. Listening

6. Writing

7. Communication and culture

8. Looking back and project

Reading is the part right after getting started and language, when students have already been introduced to the topic and vocabulary, grammar and pronunciation. The length of the reading texts may vary, depending on the topic and required tasks, but each reading passage is frequently about 200 to 250 words.

Within the limited time, only lexical cohesion in the textbook Tiếng Anh 10 published by Vietnam Education Publishing House was investigated in the study. Furthermore, not all reading texts of this book were analyzed but the authors focused only on reading texts in Reading sessions in each unit. The book consists of 10 units; each has a reading text, thus there would be 10 reading texts to go over to serve as data in this study.

Quantitative approach was applied to get the statistics from lexical cohesive items in the reading texts. Analytical and synthetic methods were also employed to draw some main features from the linguistic analysis. The process of the research was to follow several steps. First, the researchers obtained profound knowledge through referring to various resources in the field of cohesion and discourse analysis. Then, among these materials, the next task was to decide which one could be applied to set the framework of analyzing lexical cohesive devices. The choice of the research was the theoretical base in cohesion by Halliday and Hasan (1976). The following steps would be for researchers to dig deeper into details in each reading text by analyzing lexical cohesive devices then count the number of occurrences in each category. After that, the researchers could synthesize these figures in the form of tables and give comments and draw some main features of lexical cohesive devices used in the reading texts.

\section{Findings and discussion}

\subsection{Reiteration}

As aforementioned, according to Halliday and Hasan (1976, p. 288), reiteration cohesive devices consist of repetition, synonym, superordinate and general words.
As shown from the analysis of the reading texts in the textbook, reiteration includes 124 items with the contribution of each type shown in the table below:

\section{Table 1}

Number of Reiteration's Occurrence in the Reading Texts

\begin{tabular}{ccc}
\hline $\begin{array}{c}\text { Types of } \\
\text { reiteration }\end{array}$ & $\begin{array}{c}\text { Number of } \\
\text { items }\end{array}$ & $\begin{array}{c}\text { Percentage } \\
(\%)\end{array}$ \\
\hline Repetition & 86 & 69.3 \\
Synonym & 24 & 19.3 \\
Superordinate & 11 & 8.9 \\
General words & 3 & 2.5 \\
\hline
\end{tabular}

From Table 1, it is obvious that the number of repetition items outnumbers that of the others by a wide margin. Its percentage of frequency is up to $69.3 \%$. This figure can be explained by the fact that the textbook is designed for students at pre-intermediate levels. Therefore, the language used in reading texts should be as clear and simple as possible for students to easily follow. Moreover, these repeated words are theme-based and directly related to the topic, making the texts more coherent. For example, in Unit 1 students are introduced to the topic named family life. In the reading lesson of the unit, students read about household chores and duties. That is why we find many repeated words relating to the topic such as 'family' (5 times), 'share' (4 times), 'household chores' (twice), 'responsible' (twice) and so on. Below are some examples:

Acupuncture is one of the oldest medical treatments in the world. It originated in China more than 2,500 years ago. The practice of acupuncture is rooted in the idea of promoting harmony between humans and the world around them and a balance between yin and yang. Although there are unanswered questions, acupuncture appears to work. Scientific studies offer evidence that it can ease pain and treat from simple to complicated ailments. (Hoang, 2013, p. 19)

People volunteer for a number of different reasons. One of the more obvious reasons why people volunteer is because they find something they are passionate about and want to do something good for others. Many people who volunteer think that they are very fortunate to live the way they do and want to give something 
back to society, as a way of balancing the scales. (Hoang, 2013, p. 41)

However, the excessive use of repetition makes reading texts monotonous. Thus, synonym can be an alternative way to make the texts hang together in terms of language. Synonym, which consists of 24 pairs of words, is the second most common reiteration item used. It is recognizable that most synonyms are of nouns while some are verbs and adjectives. The sentences below are the prime examples:

In many cultures, doing housework is considered a woman's duty. The mother is usually the homemaker, who has to do most of the household chores, while the father is the breadwinner, who is responsible for the family finances. (Hoang, 2013, p. 9)

Acupuncture is one of the oldest medical treatments in the world. It originated in China more than 2,500 years ago. The practice of acupuncture is rooted in the idea of promoting harmony between humans and the world around them and a balance between yin and yang. (Hoang, 2013, p. 19)

Superordinate takes up a slightly smaller percentage of $8.9 \%$. Below are two examples of superordinate used in reading texts.

The most common side effects with acupuncture are soreness, slight bleeding, or discomfort. (Hoang, 2013, p. 19)

The phrase "side effects" is the superordinate of 'soreness', 'slight bleeding', and 'discomfort'.

Volunteer work is a great way to gain experience in a broad range of fields. You can gain experience in education, social work, health care, marketing, and web design. (Hoang, 2013, p. 41)

The phrases 'education', 'social work', 'health care', 'marketing', and 'web design' are hyponyms of the superordinate 'fields'.

General words are less frequently used compared to the other types of reiteration. Below are two examples of general words.

One of the more obvious reasons why people volunteer is because they find something they are passionate about and want to do something good for others. (Hoang, 2013, p. 41)

Animals can do many things humans cannot, like flying or staying underwater for a long time. (Hoang, 2013, p. 51)
The findings of this study are in line with those in the research titled "Cohesive devices in reading texts in the book Tiếng Anh $12 \mathrm{Ban} \mathrm{co}^{\circ}$ bản" (Bui, 2011). Both indicate that repetition is the most frequent reiteration used in all analyzed reading texts, followed by synonym or near synonym. The least commonly used items are superordinates and general words. Besides, all types of reiteration have one thing in common, that is one lexical item refers back to another in the preceding sentence. The high occurrence of reiteration appears to make lexical items in the reading text semantically related. This assists students in enhancing reading comprehension by strategies such as skimming, scanning and summarizing because of their tendency to base on keywords and referents to deal with follow-up exercises. Take Tiếng Anh 10 volume 1, Unit 1: Family Life (Hoang, 2013, p. 9) as a prime example:

In this unit, the aim of the reading lesson is to read and understand the text about the roles of the family by skimming and scanning the text to get some specific ideas. In exercise 2, students are required to find the title of the passage.

A. Doing housework is good for children

B. Husbands who share housework make their wives happy

C. Sharing housework makes the family happier

Students are advised to use skimming and predicting strategies based on repetition and synonyms. The cohesive devices can be shown in this text as below.

Repetition: 'family' (5 times), 'share' (4 times), 'relationships' (3 times), 'children' (3 times), 'husbands' (3 times), 'women' (2 times), 'household chores' (2 times), 'mother' (2 times), 'responsible' (2 times) and 'better' (2 times)

Synonym: 'household chores' 'housework', 'duty' - 'responsibility', 'dad' 'father', 'mum' - 'mother'

The presence of repeated words and synonyms highlights the topic of the reading text, making it easier for students to grasp the overall meaning, thus choosing title $\mathrm{C}$.

\subsection{Collocation}

Collocational items are used in all investigated reading texts; however, the density varies greatly in each unit due to different 
reading topics and the number of words. According to Halliday and Hasan (1976, p. 287), the specific items occurring in collocational environment are variable and complex. For this point, it is hard to exactly count the number of occurrences of all collocations; therefore, the researchers can only synthesize the chains of collocational cohesion in each unit as below.

\section{Table 2}

\section{Collocational Items in the Reading Texts}

\begin{tabular}{|c|c|c|}
\hline Unit & Reading topics & Collocational items \\
\hline 1 & $\begin{array}{c}\text { Household } \\
\text { chores and duties }\end{array}$ & $\begin{array}{l}\text { do housework... share household chores; homemaker... breadwinner... mother... } \\
\text { father... dads... moms... children... husbands... wives... family; responsible... } \\
\text { sociable... good... happy }\end{array}$ \\
\hline 2 & Acupuncture & $\begin{array}{c}\text { acupuncture ... acupoints... needles; ease... pain... treat ailment... promote the } \\
\text { body's natural healing capabilities... enhance its functions... medicine; side effects... } \\
\text { soreness... slight bleeding... discomfort... feel tired; scientific... studies... real } \\
\text { evidence; harmony... balance... yin and yang }\end{array}$ \\
\hline 3 & TV shows & $\begin{array}{c}\text { idol... pop... idol... American... idol... Vietnam idol... viewers... programme... } \\
\text { rating... seasons... auditions... semi-finals... finals... contestants... stage... } \\
\text { audience... competition; launched... watched... aired... performed live; countries... } \\
\text { territories... worldwide... global }\end{array}$ \\
\hline 4 & $\begin{array}{l}\text { Why people do } \\
\text { volunteer work }\end{array}$ & $\begin{array}{c}\text { volunteers... passionate... dedicated... do something good for others... give } \\
\text { something back to society... volunteering... volunteer work... work for free... gain } \\
\text { experience... gain valuable skills; }\end{array}$ \\
\hline 5 & $\begin{array}{c}\text { Inventions based } \\
\text { on nature }\end{array}$ & $\begin{array}{c}\text { aeroplane... submarine... self-cleaning glass window... hook-and-loop fastener... } \\
\text { spacesuits; observing... design... scientists ... invented... engineer... inventors... } \\
\text { technologies; lotus plants... leaves... seeds; dolphins... underwater... undersea... } \\
\text { submarine }\end{array}$ \\
\hline 6 & $\begin{array}{l}\text { Gender equality } \\
\text { and employment }\end{array}$ & $\begin{array}{l}\text { girl... gender preference... boy... gender discrimination... female... women... } \\
\text { male... man... gender differences; gender discrimination...; applied for a position... } \\
\text { failed the test... passed... do the same job... work hard... pursuing a job. }\end{array}$ \\
\hline 7 & $\begin{array}{l}\text { Superstition in } \\
\text { Viet Nam }\end{array}$ & $\begin{array}{c}\text { superstitions... superstitious... mysteries... legends... belief... rituals... believe; } \\
\text { weddings... funerals... house moving days... Vietnamese New year... Tet } \\
\text { holiday... festivals; altar... ancestors... death... souls }\end{array}$ \\
\hline 8 & $\begin{array}{l}\text { New ways to } \\
\text { learn English }\end{array}$ & $\begin{array}{l}\text { technology ... new applications... digital... media player... mobile devices... apps... } \\
\text { voice recognition... screen... software ... recorder... cameras... recording; } \\
\text { technology... useful... portable... excellent.... easier... faster... more effective... } \\
\text { more enjoyable; learning English... electronic dictionary ... digital lesson... words... } \\
\text { wordlists... exercises... tests... games... pronunciation... native English speakers... } \\
\text { English learning software... accents... English speech... song... English language } \\
\text { films... download... listen... study... improve pronunciation... practice... record... } \\
\text { learn }\end{array}$ \\
\hline 9 & $\begin{array}{l}\text { Threats to the } \\
\text { nature } \\
\text { environments }\end{array}$ & $\begin{array}{l}\text { environmental pollution... air pollution... water pollution... pollutants... soil } \\
\text { pollution... noise pollution... environmental problems... greenhouse effect... global } \\
\text { warming... polar ice melting... rise of sea level... loss of land... unclean... } \\
\text { contaminated... destruction; plastic and inorganic waste... chemical fertilizers... } \\
\text { pollutants... detergents... pesticides... chemicals; soil pollution... ground... } \\
\text { agriculture... contaminated vegetation... decrease of soil fertility; diseases... } \\
\text { stress... psychological and health problems... increased heart rate... hearing damage }\end{array}$ \\
\hline 10 & $\begin{array}{l}\text { The benefits and } \\
\text { principles of } \\
\text { ecotourism }\end{array}$ & $\begin{array}{l}\text { tourism... ecotourism... tourists... national parks... tour guides... travel } \\
\text { brochures... ecotourism destinations; forests... beaches... fauna and flora... } \\
\text { nature ... wildlife... rainforests... volcanoes...; destructions... destroy... harming... } \\
\text { preservation... protection; culture ... lifestyles... ways of life... traditions }\end{array}$ \\
\hline
\end{tabular}

It is noted that collocational items in all reading texts are largely independent of neither the grammatical structures and words such as pronouns, prepositions, conjunctions nor reiteration like synonyms or superordinates. Another remarkable point is that the occurrence of collocational items is not limited in pairs but across sentence boundaries. Hence, collocational items in lexical cohesion is not the combination of adjacent words. On the contrary, they tend to appear in similar contexts to generate a cohesive effect, making the 
reading texts cohesive. To demonstrate the cohesive effect formed by collocational items, the authors analyzed the following part of the reading text in Tiếng Anh 10, volume 2, Unit 9: Preserving the environment.

Soil pollution is a result of dumping plastic or other inorganic waste in the ground and the overuse of chemical fertilizers in agriculture. The long-term effects of soil pollution are contaminated vegetation and the decrease of soil fertility. (Hoang, 2013, p. 41)

The chain of collocational items in the example is "soil pollution... plastic... inorganic waste... chemical fertilizers... contaminated vegetation... decrease of soil fertility". It is obvious that they are not adjacent words nor reiteration, but they all indicate the collocational environment "soil pollution". When the topic of soil pollution is discussed, these aforementioned words tend to co-exist with each other. "Chemical fertilizers" ties with "plastic" and "inorganic waste" in the preceding part, and less directly, with the words "soil pollution", "contaminated vegetation", "decrease of soil fertility". The reason for this comes from the meaning of these two sentences. While "chemical fertilizers", "plastic" and "inorganic waste" in the first sentence are causes of soil pollution, "contaminated vegetation" and "decrease of soil fertility" in the second one are regarded as "long-term effect". The use of collocational items in this example enables students to easily find out the answer for sentence 3 in exercise 3 in which they are asked to identify whether 6 given sentences are true or false. Sentence 3 is "Using a lot of fertilizers can reduce soil fertility" and based on collocational items students can effortlessly decide it is false.

In addition to these above-mentioned findings, it is revealed from the analysis of the reading texts that the number of lexical cohesive devices and their types in each text vary greatly according to the text's length and topic. With reference to the former, it is obvious that the longer the text is, the higher number of lexical cohesive items' occurrence the authors can find out. Also, the number of these items tends to be more densely distributed in, for example, a 250 -word text than a 150 -word one. It is easy to find lexical cohesion in almost every sentence of the longer texts. As a result, they seem to include more types of lexical cohesive devices, in other words, wide-ranging reiterations and collocations are more used than in the shorter ones. This is because the longer the text is, the more cohesive elements it needs to remain the continuity between a part of it and another. Therefore, the higher number of lexical cohesive devices is required to fulfill this task in a way that a lexical item is related to one occurring previously. In terms of reading topics, there are 10 different ones in the textbook Tiếng Anh 10 ranging from something directly related to students to less familiar issues. It is worth noting that there is a marked difference in the number of lexical cohesion's distribution in each text. Certain topics seem to have more collocational items than the others, whereas some have more reiterations. However, the reading texts about some seemingly less common topics for students (acupuncture, inventions based on nature, superstition, etc.) tend to comprise a higher number of reiterations than familiar ones (household chores, TV shows, etc.). The reason for this may come from the fact that unfamiliar reading topics are mostly out of students' interest or students have little background knowledge of them. There is a high tendency for these kinds of reading texts to include more technical terms and advanced vocabulary, so the wide range of reiterations will turn texts of difficult topics into easy-tounderstand ones. Coupled with chains of collocational items, the use of repetitions, synonyms, superordinates and general words can assist students immensely in interpreting the text based on lexical environment and related words occurring previously.

The following examples illustrate this relationship between lexical cohesive devices and the text's length and topic. The researchers choose to analyze two reading texts from Tiếng Anh 10 volume 1 , one is a 160 -word text about TV shows from Unit 3 (Hoang, 2013, p. 29) and another has 350 words of acupuncture from Unit 2 (Hoang, 2013, p. 19). Apart from collocational items shown in Table 2, it is evident that the later has a more frequent occurrence of reiterations than the former. For example, in the text of Unit 3, repetition is used for 6 words including "contestants", "countries", "became", "aired", "viewers" and "Idol" with the word "Idol" is repeated most (4 times), whereas the reading passage in Unit 2 has 10 repeated words such as "acupuncture", "points", "acupoints", "treatment", "body", "promote", "needles", "people", "medicine" 
and "survey" with the highest number of repeated times is "acupuncture". Synonyms are used in both reading texts but the text about TV shows has two pairs of synonyms ("countries""territories" and "global"-"worldwide") while another text consists of more synonyms ("originated"-“rooted", “enhance"-“promote", "inside"-“inner", "pressure points"-“acupoints", "care"-"precautions"). Also, a higher number of superordinates can be seen the longer text in which there are 2 items ("side effects" is a superordinate of "soreness", "slight bleeding" and "discomfort" and "treatment" is a superordinate of "acupuncture"), while the shorter one has "the show" as a superordinate of "Idol", "Pop Idol" "Viet Nam Idol" and "American Idol". In addition to reiterations, chains of collocational items in the text of acupuncture are more than those of TV shows. This can be seen in Table 2. Another interesting point is that the more frequently lexical cohesive devices occur, the more demanding topic the text has. While the reading topic of Unit 3 related to music is more of students' interest and understanding, the other is a more challenging topic which is about a kind of treatment for the body. The higher number of lexical cohesion's occurrence enables students to easily have a better grasp of the text related to acupuncture based on the link between one part and another preceding. Therefore, it is unnecessary for them to understand every single word to function successfully on reading texts of complex or unfamiliar topics. However, these texts themselves include lexical cohesive devices as reading guides and it is the readers' task to take full advantage of them.

From the above-mentioned findings and discussions, some conclusions of lexical cohesive devices' meaning for the reading texts and students' reading skills could be drawn. Cohesion provides for a text a semantic unit or the sort of continuity that exists between a part of the text and another (Halliday, 1976, p. 209). This enables readers to understand all missing pieces which are not present in the text but are necessary to its interpretation. For example, cohesion in a reading passage of Unit 10 Ecotourism, Tiếng Anh 10 volume 2 (Hoang, 2013 , p. 51) provides a semantic unit of the benefits and principles of ecotourism, which allows students imagine the context and use their background knowledge related to this topic to interpret the text more easily. More specifically, lexical cohesion is established through the structure of vocabulary and involves the selection of lexical items that is in some way related to one occurring previously (Halliday, 1976, p. 303). The use of reiterations and collocations makes a word associate with another in the preceding in many ways such as directly repeating, creating synonyms, or occurring in the same lexical environment. This makes the reading texts more cohesive and more importantly, students can benefit greatly from the occurrence of lexical cohesive devices. In the reading lessons studying the textbook Tiếng Anh 10, students are supposed to get familiar with different types of reading questions using some strategies namely scanning, skimming, inferring, and summarizing. Question types may range from matching words with their meaning, choosing the text's title, deciding whether sentences given are true/false/not given, giving short answers, and doing multiple-choice questions. In the process of reading, students cannot avoid encountering new words especially in the texts of unfamiliar topics, but thanks to the high occurrence of cohesive devices, they can guess their meaning based on context generated by the other words occurring previously. In particular, based on repeated words and synonyms, students tend to find it easier to grasp the main idea of the test, and with the aid of chains of collocations they can locate information accurately to deal with questions related to detailed information. If a text fails to use lexical cohesive devices, not only does it lack continuity of lexical meaning but also students will find difficulty in interpreting the text and finding the answer to reading questions. Besides, all reading texts in the textbook are useful learning materials for students in improving both their reading skills and other skills. When students frequently get exposed to reading texts with a high distribution of lexical cohesive items, it is a great opportunity to learn from the use of cohesion in writing more cohesive essays as well. 


\section{Conclusion and implications}

The study results show that there is a high occurrence proportion of lexical cohesive devices in 10 analyzed reading texts in Tieng Anh 10. It seems that repetition - a type of reiteration and collocation are densely used throughout all the reading texts. Not only does this provide a semantic unit of the text but such lexical cohesion also generates a marked cohesive effect across sentence boundaries. Added to this, it can be safely assumed that lexical cohesive devices are an essential tool to aid students' reading comprehension with regard to understanding texts at ease. It is unnecessary for them to grasp the meaning of every single word, but they can use the surrounding words and the link among sentences and ideas as reading guides. As a result, students are likely to manage the reading tasks effectively and their lexical resources are boosted significantly.

Due to limited time, the study investigates only lexical cohesive devices without analyzing grammatical ones. The research would have been of more importance if there had been analysis of both grammatical cohesion and lexical cohesion so that it offers deeper insights into the use of cohesion in reading texts in Tiếng Anh 10. Another point to bear in mind is this article is basically a preliminary study in the way that it solely figures out the lexical cohesive devices without proposing suggestions for applications on teaching. Thus, this article's findings will hopefully offer recommendations for further studies on applying lexical cohesion in teaching and learning reading comprehension or writing.

\section{References}

Adel, E., \& Saeide, E. (2013). Awareness of Lexical Cohesive Devices in Text and Reading Comprehension. International Journal of Educational Research \& Technology, 4(2), 63-65.

Bui, T. N. (2011). Cohesive devices in reading texts in the book Tiếng Anh 12 Ban co bản [Master's thesis, Vietnam National University, Hanoi]. VNU Repository. http://repository.vnu.edu.vn/handle/VNU_123/39977

Clark, C., \& Rumbold, K. (2006). Reading for pleasure: A research overview. National Literacy Trust.

Crystal, D. (1992). Introducing linguistics. Penguin English.

David, N. (1993). Introducing discourse analysis. Penguin English.

Duffy, G. G. (2009). Explaining reading: A resource for teaching concepts, skills and strategies (2nd ed.). The Guildford Press.

Halliday, M. A. K., \& Hasan, R. (1976). Cohesion in English. Longman.

Halliday, M. A. K., \& Hasan, R. (1989). Language, context and text: Aspects of language in a socialsemiotic perspective (2nd ed.). Oxford University Press.

Hoang, V. V. (2013). Tiếng Anh 10: Sách họ sinh (English 10: Student's book). Vietnam Education Publishing House.

Koda, K. (2005). Insights into second language reading: A cross-linguistic approach. Cambridge University Press.

McCarthy, M. (1991). Discourse analysis for language teachers. Cambridge University Press.

Paltridge, B. (2012). Discourse analysis: An introduction. Continuum.

Pamela, J. S. (2004). Barron's How to prepare for the TOEFL IBT (11th ed.). Barron's Educational Series, Inc.

Smith, F. (2004). Understanding reading: A psycholinguistic analysis of reading and learning to read (6th ed.). Lawrence Erlbaum Associates.

Soraya, B. (2012). Teaching grammatical cohesive devices to enhance reading comprehension: The case of first year students - University of Larbi Ben M'hidi, Oum El-Bouaghi [Master's thesis, Constantine University]. http://bu.umc.edu.dz/theses/english/BEC1332.pdf 


\title{
NGHIÊN CÚU SO’ BỘ VỀ PHƯƠNG TIỆN LIÊN KẾT TƯ VỰNG TRONG CÁC BÀI ĐỌC TRONG SÁCH GIÁO KHOA TIẾNG ANH 10 CỦA NHÀ XUẤT BẢN GIÁO DỤC VIỆT NAM
}

\author{
Nguyễn Hoàng Minh ${ }^{1}$, Đồng Thị Thủy ${ }^{2}$ \\ 1. Đại học Huddersfield, Queensgate, Huddersfield, HD3 3DH, Vuơng quốc Anh \\ 2. Đại học Su phạm Hà Nội, 136 Xuân Thủy, Cầu Giấy, Hà Nội, Việt Nam
}

Tóm tắt: Nghiên cứu xem xét các phương tiện liên kết từ vựng trong sách giáo khoa Tiếng Anh 10 do Nhà xuất bản Giáo dục Việt Nam xuất bản. Nghiên cứu này sử dụng phương pháp phân tích tài liệu để trả lời câu hỏi nghiên cứu. Đặc biệt, mười bài đọc trong phần kỹ năng đọc được nghiên cứu dựa trên lý thuyết của Halliday và Hasan (1976) về liên kết trong diễn ngôn. Kết quả nghiên cứu cho thấy phép lặp được sử dụng nhiều nhất trong tất cả các bài đọc để tạo nên liên kết về ngữ nghĩa, trong khi đó liên kết về trường từ vựng tạo hiệu ứng gắn kết giữa các từ và cụm từ trong cùng một trường nghĩa. Dựa vào sự gắn kết từ vựng đó, học sinh sẽ dễ் dàng nắm bắt ý nghĩa của các bài đọc, và nâng cao khả năng đọc hiểu và vốn từ vựng theo chủ đề. Hy vọng rằng bài báo này là một nghiên cứu sơ bộ cho những nghiên cứu sâu hơn về việc áp dụng liên kết từ vựng trong dạy và học kỹ năng đọc hiểu hoặc viết.

Từ khóa: kỹ năng đọc, phương tiện liên kết, phương tiện liên kết từ vựng, phân tích diễn ngôn, Tiếng Anh 10 